\title{
Mechanisms on inhibition of photosynthesis in Kandelia obovata due to extreme cold events under climate change
}

\author{
Chunfang Zheng ${ }^{1}$, Jianwu Tang ${ }^{2}$, Jinong Chen ${ }^{1}$, Weicheng Liu ${ }^{1 *}$, Jianbiao Qiu', Xin Peng ${ }^{1}$ and Yong Y $e^{3^{*}}$
}

\begin{abstract}
Introduction: Mangroves that grow at the latitudinal extremes of their distribution are susceptible to extreme cold events. Successive enhancement of low temperature stress (seLTS) is a typical characteristic of extreme cold events. Low temperature stress can inhibit mangrove photosynthesis, which often inhibits the growth and development of mangroves. However, the possible reasons for impairment to photosynthesis of mangroves due to extreme cold events remain unclear.
\end{abstract}

Methods: Kandelia obovata seedlings in a growth chamber were exposed to $5^{\circ} \mathrm{C} /-2^{\circ} \mathrm{C}$ (day/night) for $36 \mathrm{~h}$ $\left(-2^{\circ} \mathrm{C}\right.$ for $16 \mathrm{~h}$ ) with $12 \mathrm{~h}$ light per day at $600 \mu \mathrm{mol} \mathrm{m} \mathrm{m}^{-2} \mathrm{~s}^{-1}$ photosynthetic photon flux density (PPFD) (a low temperature stress, aLTS), then the plants were transferred to the control condition $\left(15^{\circ} \mathrm{C} / 10^{\circ} \mathrm{C}\right.$ (day/night) and allowed to recover for 5 days (R1). The other seedlings were subjected to low temperature treatment with a day/night temperature of $5^{\circ} \mathrm{C} /-1^{\circ} \mathrm{C}$ in a growth chamber for $24 \mathrm{~h}$. Then these plants were transferred to $5^{\circ} \mathrm{C} /-2^{\circ} \mathrm{C}$ (day/night) under the same light and climate conditions for $36 \mathrm{~h}$ (two low temperature stresses, tLTS). Following the successive enhancement of low temperature treatment, these plants were returned to $15^{\circ} \mathrm{C} / 10^{\circ} \mathrm{C}$ (day/night) for another 5-day recovery period (R2).

Results: Results showed that aLTS treatment significantly reduced leaf net photosynthetic rate $\left(P_{\mathrm{n}}\right)$ and stomatal conductance $\left(G_{\mathrm{s}}\right)$, while increased intercellular $\mathrm{CO}_{2}$ concentration $\left(C_{\mathrm{i}}\right)$. Photosynthetic activity of leaves quickly recovered after the plants were returned to control temperature for 5 days (R1). However, decreases in leaf $P_{\mathrm{n}}$ were more obvious under tLTS treatment than those under aLTS treatment. This reduced $P_{\mathrm{n}}$ might be attributed to stomatal and non-stomatal limitations. Moreover, non-stomatal limitation played a major role in reducing $P_{\mathrm{n}}$ during tLTS treatment, as proven by reduced ribulose 1,5-biphosphate carboxylase (RuBPCase) activity. This limitation also enhanced lipid peroxidation in chloroplasts, decreased sucrosemetabolizing enzymes and ratios of both chlorophyll a/chlorophyll b $(\mathrm{Chl} \mathrm{a} / \mathrm{b})$ and chlorophyll/carotenoids (Chl/Car), and increased protease senescence. Damages of tLTS treatment to photosynthesis were insufficiently alleviated even after the plants were returned to control temperature for 5 days (R2).

(Continued on next page)

\footnotetext{
*Correspondence: Izlzly2010@126.com; yeyong@xmu.edu.cn

'Zhejiang Mariculture Research Institute, Zhejiang Key Laboratory of Exploitation and Preservation of Coastal Bio-resource, Wenzhou 325005,

Zhejiang, People's Republic of China

${ }^{3}$ Key Laboratory of the Ministry of Eduction for Coastal and Wetland

Ecosystem, College of the Environment and Ecology, Xiamen University,

Xiamen 361005, People's Republic of China

Full list of author information is available at the end of the article
} 
(Continued from previous page)

Conclusions: Successive enhancement of low temperature depressed successful recovery of leaf photosynthesis of K. obovata seedlings mainly by impairing pigment synthesis, antioxidant metabolism, and sucrose translocation, as well as accelerating senescence of endopeptidase. Furthermore, our results suggest that decreases in sucrose content in leaves might also account for increases in reactive oxygen species (ROS) in chloroplasts.

Keywords: Kandelia obovata, Low temperature, Gas exchange, Sucrose synthesis, Peptidase

\section{Introduction}

Low temperature is a major environmental constraint for plants as a result of the injury provoked on leaf photosynthesis. Chloroplasts are the site of photosynthesis in cells and are a rich source of reactive oxygen species (ROS). ROS production is dramatically enhanced in response to adverse environmental conditions, often resulting in an excessive demand of the cellular antioxidant machinery (Fahnenstich et al. 2008). In general, to limit the action of ROS, plant cells evolve anti-oxidative systems including superoxide dismutase (SOD, EC 1.15.1.1), ascorbate peroxidase (APX, EC 1.11.1.11), and peroxidase (POD, EC 1.11.1.7). Inhibition of antioxidant enzyme activities by chilling stress leads to production of ROS, which confers serious oxidative damages to Zingiber officinale ( $\mathrm{Li}$ et al. 2014). Moreover, a significant rise in $\mathrm{H}_{2} \mathrm{O}_{2}$ content in the leaves of cucumber, as well as higher activities of APX and SOD in the leaves, was found under low temperature stress (Lee et al. 2004). When tomato leaves are exposed to low temperature stress, sucrose contents are determined by photosynthetic rate, and sucrose phosphate synthase (SPS) activity is determined by sugar concentration (Artuso et al. 2000). That is, variations in photosynthesis are related to stomatal closure, leaf chlorosis, chloroplast malfunction, photo-inhibition or photo-oxidation, and sucrose metabolism. However, it is unclear whether physiological metabolic processes that depress the photosynthesis of mangroves have unique characteristics, in comparison with terrestrial plants.

The latitudinal distribution of mangrove species is limited mainly by temperature-related drivers (Quisthoudt et al. 2012). Mangroves are mainly tropical tree species that grow in the intertidal zone of tropical and subtropical coasts. According to the tropical origin, climate warming may enable mangroves to extend their distribution to higher latitudes (Gilman et al. 2008; Naidoo 2016). However, mangroves that lie along the latitudinal extremes of their distribution are still vulnerable to the extreme cold events (Ellis et al. 2006; Gilman et al. 2008, Saintilan et al. 2014). In general, successive enhancement of low temperature is a typical characteristic of extreme cold events. Several researches reported that low temperature, especially freezing stress, seriously influenced mangrove development and survival (Ellis et al. 2006; Stuart et al.
2006; Liu et al. 2014). For example, a severe winter in Florida, occurred between the 1995 and 1996 growing seasons (minimum air temperature of $-8^{\circ} \mathrm{C}$ in January 1996), killed $12 \%$ mangrove trees, and the severe freeze season occurred once approximately 8 years (Stevens et al. 2006; Ross et al. 2009). Studies have shown that frost may restrict nutrient resorption during leaf senescence. $K$. obovata resorbed $61 \% \mathrm{~N}$ and $42 \% \mathrm{P}$ during normal leaf senescence (Wang et al. 2011). Peng et al. (2013) found that three CBF/DREB1 (C-repeat binding factor/dehydration responsive element-binding factor 1) genes play different roles in Avicennia marina, and the AmCBF2 might be involved in the signaling pathway of cold stress response. But little attention has been paid to physiological mechanisms on these damages to mangroves by seLTS.

$K$. obovata Sheue et al. (2003) is a common mangrove species along southeastern coastlines of China. This species has high tolerance against low temperature stress. However, low temperature still decreases the total number of leaves that emerge from $K$. obovata yearly (Analuddin et al. 2009). In 2010, a blizzard severely damaged or killed many mangrove trees in southern China. It was found that seLTS severely damaged the development of K. obovata by disturbing photosynthetic capacity in the Yueqing bay, Zhejiang Province, China (Zheng et al. 2013). Unfortunately, the possible reasons for impairment to photosynthesis of mangroves by seLTS remain unclear. In the present study, we investigated the effects of seLTS and subsequent recovery on photosynthetic characteristics, photosynthetic pigment contents, chloroplast anti-oxidation system, sucrose synthesis, and proteolysis in the leaves of $K$. obovata seedlings to assess harmful effects on photosynthesis and find reasons for reduction in photosynthesis. These efforts will be useful in restoring and protecting mangrove forests especially in high latitude area.

\section{Methods}

\section{Plant materials and culture}

Propagules of $K$. obovata were collected from Fuding (the northern limit of natural mangrove distribution in China, $27^{\circ} 17^{\prime} \mathrm{N}$ ), Fujian Province, China. Undamaged propagules with $12 \pm 0.5 \mathrm{~cm}$ length were randomly planted in plastic pots $(30 \mathrm{~cm}$ in height and $20 \mathrm{~cm}$ in diameter) filled with $3.0 \mathrm{~kg}$ of intertidal soil and 
maintained in a temperature-controlled growth chamber under $25^{\circ} \mathrm{C} / 20^{\circ} \mathrm{C}$ day/night cycles. The everyday light and climate conditions in this chamber were $12 \mathrm{~h}$ of light at $600 \mu \mathrm{mol} \mathrm{m} \mathrm{m}^{-2} \mathrm{~s}^{-1}$ photosynthetic photon flux density (PPFD) and $70 \%$ relative humidity. The pots were immersed in nutrient solution (Haines and Dunn 1976), which was replenished once a week.

\section{Experimental treatments}

The experiment was conducted in Wenzhou $\left(28^{\circ} 1^{\prime} \mathrm{N}\right)$, Zhejiang Province, China. Wenzhou is the northern limit of mangroves introduced in China. In Wenzhou, extreme low temperatures sporadically occur, causing substantial frost damage to mangroves. In January, 2011, low temperature in mangrove communities steadily decreased, and the minimal air temperature dropped from $-1.1^{\circ} \mathrm{C}$ (about $10 \mathrm{~h}$ in $24 \mathrm{~h}$ ) to $-3.2^{\circ} \mathrm{C}$ (about $4 \mathrm{~h}$ in $72 \mathrm{~h}$ ). The lowest temperature occurred during flood tide and the minimal surface seawater temperature during this period was about $5.5^{\circ} \mathrm{C}$. The seedlings of $K$. obovata were therefore protected by warmer seawater. But seedlings were exposed to freezing temperature $\left(-2.0^{\circ} \mathrm{C}\right)$ for about $16 \mathrm{~h}$ in $72 \mathrm{~h}$. That is, there was a rare cold event in 2011, resulting in badly damaged mangroves (Zheng et al. 2016). To simulate this cold event, an experiment was performed as follows: The seedlings were maintained at $15^{\circ} \mathrm{C} / 10^{\circ} \mathrm{C}$ day/night (near minimum monthly mean temperature in Wenzhou) with $12 \mathrm{~h}$ light per day at $600 \mu \mathrm{mol} \mathrm{m} \mathrm{m}^{-2} \mathrm{~s}^{-1}$ PPFD for 15 days. Then, they were divided into three batches after the tenth pair of leaves expanded. One batch was in a chamber at a day/night temperature of $15^{\circ} \mathrm{C} / 10^{\circ} \mathrm{C}$ (control plants). Another batch in a growth chamber was exposed to $-2^{\circ} \mathrm{C}$ from 8:00 pm to 8:00 am in the next morning in the dark and then the temperature was shifted to $5^{\circ} \mathrm{C}$ from $-2^{\circ} \mathrm{C}$ for $12 \mathrm{~h}$ with light at $600 \mu \mathrm{mol} \mathrm{m}{ }^{-2} \mathrm{~s}$ ${ }^{-1}$ PPFD. Afterwards, the seedlings continuously grew at $-2^{\circ} \mathrm{C}$ for $4 \mathrm{~h}$ in the dark and at $5^{\circ} \mathrm{C}$ for $8 \mathrm{~h}$ with light at $600 \mu \mathrm{mol} \mathrm{m} \mathrm{m}^{-2} \mathrm{~s}^{-1}$ PPFD. This treatment was designated as a low temperature stress (aLTS). After aLTS treatment, the plants were transferred to the control condition and allowed to recover for 5 days (R1). The last batch was subjected to low temperature treatment with a night temperature of $-1^{\circ} \mathrm{C}$ in a growth chamber from 8:00 pm to 8:00 am in the next morning in the dark, then the day temperature was $5^{\circ}$ $C$ with light at $600 \mu \mathrm{mol} \mathrm{m} \mathrm{m}^{-2} \mathrm{~s}^{-1}$ PPFD by setting the control from 8:00 am to 8:00 pm. Then, these plants were allowed to continue processing according to the methods of aLTS treatment (designated as two low temperature stresses (tLTS)). Following the successive enhancement of low temperature treatment, these plants were returned to $15^{\circ} \mathrm{C} / 10^{\circ} \mathrm{C}$ (day/night) for another 5-day recovery period (R2). In total, three treatments were established. Physiological parameters were determined by using the second pair of fully expanded leaves. The experiment was replicated in five separate plants for each treatment.

\section{Gas exchange assay}

Net photosynthetic rate $\left(P_{\mathrm{n}}\right)$, stomatal conductance $\left(G_{\mathrm{s}}\right)$, and intercellular $\mathrm{CO}_{2}$ concentration $\left(C_{\mathrm{i}}\right)$ were measured on the youngest fully expanded leaves using a Li-6400 portable photosynthesis system (LiCor, Lincoln, NE, USA). A leaf chamber equipped with a red/blue LED light source was used. All measurements were taken at a constant flow rate of $500 \mathrm{~mL} \mathrm{~min}^{-1}$ and $\mathrm{CO}_{2}$ concentration of $390 \mu \mathrm{mol} \mathrm{mol}^{-1}$ under a photosynthetically active radiation of $600 \mu \mathrm{mol} \mathrm{m}{ }^{-2} \mathrm{~s}^{-1}$.

\section{Leaf chlorophyll content assay}

The youngest fully expanded leaf sample $(0.1 \mathrm{~g})$ was sliced and incubated in $50 \mathrm{~mL}$ of pigment extraction solution containing acetone and anhydrous ethanol $(1: 1, v / v)$ in the dark for $24 \mathrm{~h}$ at $25^{\circ} \mathrm{C}$. Chlorophyll contents were determined as described by Arnon (1949).

\section{Ribulose 1,5-biphosphate carboxylase activity assay}

RuBPcase activity was determined according to the method of Sui et al. (2005) by spectrophotometry. In brief, the reaction mixture was comprised of $5 \mathrm{mM}$ $\mathrm{NADH}, 50 \mathrm{mM}$ ATP, $50 \mathrm{mM}$ phosphocreatine, $0.2 \mathrm{mM} \mathrm{NaHCO} 3,100 \mathrm{mM}$ Tris- $\mathrm{HCl}$ buffer ( $\mathrm{pH} 7.8$ ), $12 \mathrm{mM} \mathrm{MgCl}_{2}, 0.4 \mathrm{mM}$ EDTA-Na, $160 \mathrm{U} \mathrm{mL}^{-1} 3$ phosphoglycerate kinase, glyceraldehyde-3-phosphate dehydrogenase, creatine phosphokinase, and $0.1 \mathrm{~mL}$ enzyme extract solution. The changes of $\mathrm{A}_{340}$ in $1 \mathrm{~min}$ of the assay mixture were measured with a UV-VIS recording spectrophotometer (UV-160A, Shimadzu, Japan).

\section{Chloroplast preparation}

Chloroplasts were isolated using the method described by Seigneurin-Berny et al. (2008). Fresh leaves were homogenized in ice-cold isolation buffer $(0.4 \mathrm{mM}$ sorbitol, $20 \mathrm{mM}$ Tricine- $\mathrm{KOH}, 10 \mathrm{mM}$ EDTA, $10 \mathrm{mM} \mathrm{NaHCO}$, and $0.15 \%$ bovine serum albumin (BSA)). The homogenate was filtered through four layers of gauze, and the filtrate was centrifuged at $1465 \times \mathrm{g}$ for $90 \mathrm{~s}$ (including deceleration). The pellets were resuspended in $2 \mathrm{~mL}$ of buffer $(0.4 \mathrm{mM}$ sorbitol, $20 \mathrm{mM}$ Hepes- $\mathrm{KOH}, 2.5 \mathrm{mM}$ EDTA, $5 \mathrm{mM} \mathrm{MgCl}_{2}, 10 \mathrm{mM} \mathrm{NaHCO}$, and $0.15 \%$ BSA), placed into a tube containing $8 \mathrm{~mL}$ of resuspension medium with $40-80 \%(v / v)$ Percoll and then centrifuged at $13300 \times g$ for $10 \mathrm{~min}$. The chloroplasts were 
collected at the $40 \% / 80 \%$ interface. All procedures were performed at $0-4^{\circ} \mathrm{C}$.

\section{Assays of malondialdehyde content, hydrogen peroxide release, superoxide anion release rate, and antioxidant enzyme activity in leaf chloroplasts}

Malondialdehyde (MDA) content was measured in terms of the total content of thiobarbituric acid (TBA) reactive substances as described by Hodges et al. (1999). Hydrogen peroxide $\left(\mathrm{H}_{2} \mathrm{O}_{2}\right)$ content was assayed using the method by Moloi and van der Westhuizen (2006). Release rate of $\mathrm{O}_{2}^{-}$was measured as previously described by Sui et al. (2007).

Superoxide dismutase (SOD) activity was assayed following the method from Giannopolitis and Ries (1977), while peroxidase (POD) activity was measured as described by Lee and Lin (1995). Ascorbate peroxidase (APX) activity and soluble protein (SP) content were determined according to Nakano and Asada (1981) and Bradford (1976), respectively.

Total soluble sugar, sucrose, and free amino acid assays Approximately $0.1 \mathrm{~g}$ of dried leaf sample powder was extracted with $8 \mathrm{~mL}$ of $80 \%(v / v)$ ethanol. The extract was incubated at $80^{\circ} \mathrm{C}$ for $30 \mathrm{~min}$ and then centrifuged at $10000 \times g$ for $10 \mathrm{~min}$. The supernatant solution was collected. The extraction procedure was repeated thrice to ensure the complete extraction of sugars and amino acid. The total soluble sugar content was measured as previously described by Zhang et al. (2011). The sucrose content was determined by a similar method from Hendrix (1993) with minor modifications. Ethanol extract $(0.4 \mathrm{~mL})$ was mixed with $0.2 \mathrm{~mL}$ of $2 \mathrm{M} \mathrm{NaOH}$, heated in a boiling water bath for $5 \mathrm{~min}$ and then allowed to cool. The reactants were mixed with $2.8 \mathrm{~mL}$ of $30 \% \mathrm{HCl}$ and $0.8 \mathrm{~mL}$ of $0.1 \%$ resorcin $(0.1 \mathrm{~g}$ of resorcin in $100 \mathrm{~mL}$ of $95 \%$ aqueous ethanol). The mixture was incubated at $80^{\circ} \mathrm{C}$ for $10 \mathrm{~min}$. The reaction mixture was then measured at $480 \mathrm{~nm}$ absorbance.

The content of free amino acids was measured by a similar method from Moore and Stein (1954) with minor modifications. Ninhydrin reagent ( $3 \mathrm{~mL}, \mathrm{pH} 5.4$ ), distilled water $(1 \mathrm{~mL}), 0.1 \%$ ascorbic acid, and ethanol extract $(1 \mathrm{~mL})$ were mixed. The mixture was heated in a boiling water bath for $15 \mathrm{~min}$ and then allowed to cool in tap water. The content of free amino acids was spectrophotometrically determined at $570 \mathrm{~nm}$.

Sucrose phosphate synthase and sucrose synthase assays Enzyme extraction and assay were according to Hubbard et al. (1989). Approximately $0.5 \mathrm{~g}$ of fresh leaves were ground and homogenized in a prechilled mortar and pestle with $5 \mathrm{~mL}$ of extraction buffer [50 mM Mops-NaOH (pH 7.5), $5 \mathrm{mM} \mathrm{MgCl}_{2}, 1 \mathrm{mM}$
EDTA, $2.5 \mathrm{mM}$ dithiothreitol (DTT), 0.05\% $(v / v)$ Triton $\mathrm{X}-100$, and $\left.0.5 \mathrm{mg} \mathrm{mL} \mathrm{m}^{-1} \mathrm{BSA}\right]$. The homogenate was centrifuged at $10,000 \times g$ for $30 \mathrm{~min}$, and the supernatant was immediately used to analyze activities of sucrose synthase (SS) and sucrose phosphate synthase (SPS). All extraction procedures were carried out at $0-4^{\circ} \mathrm{C}$.

The assay mixture contained $50 \mathrm{mM}$ Mops- $\mathrm{NaOH}$ buffer ( $\mathrm{pH} 7.5), 15 \mathrm{mM} \mathrm{MgCl}_{2}, 5 \mathrm{mM}$ fructose-6phosphate, $15 \mathrm{mM}$ glucose-6-phosphate, $5 \mathrm{mM}$ UDPglucose, and $0.1 \mathrm{~mL}$ of enzyme extract. The mixture was incubated at $25^{\circ} \mathrm{C}$ for $30 \mathrm{~min}$, and the reaction was terminated by adding $0.1 \mathrm{~mL}$ of $2 \mathrm{M} \mathrm{NaOH}$. The tubes were placed in boiling water bath for $10 \mathrm{~min}$ and then allowed to cool. The mixture was added with $1 \mathrm{~mL}$ of $0.14 \%(w / v)$ anthrone in $13.8 \mathrm{M} \mathrm{H}_{2} \mathrm{SO}_{4}$ and then incubated in $40^{\circ} \mathrm{C}$ water bath for $20 \mathrm{~min}$. The tubes were allowed to cool, and sucrose content was spectrophotometrically determined at $620 \mathrm{~nm}$ absorbance. SS assay was the same as above, except that the reaction mixture contained $10 \mathrm{mM}$ fructose instead of fructose-6-phosphate and was devoid of glucose-6-phosphate.

\section{Endopeptidase and carboxypeptidase assays}

Enzymes were extracted according to the procedure described by Mehta and Mattoo (1996). Fresh leaves (1 g) were homogenized in $5 \mathrm{~mL}$ of refrigerated grinding medium (50 mM Tris-HCl buffer, $4 \mathrm{mM}$ DTT, $1 \mathrm{mM}$ EDTA, and 1\% PVP). The extract was centrifuged at $15000 \times g$ for $30 \mathrm{~min}$, and the supernatant was collected to estimate activities of endopeptidase and carboxypeptidase.

Carboxypeptidase activity was assayed as described by Wang et al. (2003). The reaction mixture $(0.4 \mathrm{~mL}$ of enzyme supernatant, $0.4 \mathrm{~mL}$ of $100 \mathrm{mM}$ acetate buffer, and $0.2 \mathrm{~mL}$ of $0.05 \mathrm{M}$ bovine hemoglobin) was incubated at $38^{\circ} \mathrm{C}$ for $1 \mathrm{~h}$. Then, the reaction was terminated by adding $1 \mathrm{~mL}$ of $10 \%$ TCA. After centrifugation at $4000 \times g$ for $10 \mathrm{~min}$, the suspension was used for ninhydrin reaction.

The reaction mixture for endopeptidase assay was similar to that for carboxypeptidase assay except that $0.3 \%(w / v)$ hippuryl-L-phenylalanine was used instead of $0.05 \mathrm{M}$ bovine hemoglobin. Activities of endopeptidase and carboxypeptidase were expressed in $\mu \mathrm{mol}$ $\alpha-\mathrm{NH}_{2} \mathrm{~g}^{-1} \mathrm{FW} \mathrm{h} \mathrm{h}^{-1}$.

\section{Statistical analysis}

Data of each parameter were normal and reported as mean + standard deviation (SD) of five replicates. The one-way ANOVA was used to test any significant differences among the treatments. Pearson's correlation was used to analyze relationships among physiological indices. 
Significant level was at 0.05 . All statistical analyses were performed by using the SPSS software (SPSS Ver. 19.0, Chicago, IL, USA).

\section{Results}

\section{Leaf gas exchange}

A drastic impact was found under both low temperature stresses, reaching null and negative value in $P_{\mathrm{n}}$ (Fig. 1a). Compared with the control, aLTS treatment significantly decreased $P_{\mathrm{n}}$ and $G_{\mathrm{s}}$ but significantly increased $C_{\mathrm{i}}$ in the seedling leaves of $K$. obovata $(p<0.05$, Fig. 1a-c). By contrast, no significant differences in $P_{\mathrm{n}}, G_{\mathrm{s}}$, and $C_{\mathrm{i}}$ were observed within 5 days of recovery after aLTS treatment between the stressed and control plants (Fig. 1a-c). tLTS significantly reduced $P_{\mathrm{n}}$ and $G_{\mathrm{s}}$ but significantly increased $C_{\mathrm{i}}(p<0.05) . P_{\mathrm{n}}, G_{\mathrm{s}}$, and $C_{\mathrm{i}}$ were not recovered (i.e., the values returned to the level of the control, the same as below) even after the subsequent returned to $15^{\circ} \mathrm{C} / 10^{\circ} \mathrm{C}$ (day/night) for 5 days.

\section{Pigment contents}

Treatment aLTS significantly decreased ratios of chlorophyll a/chlorophyll b ( $\mathrm{Chl}$ a/b) and chlorophyll/ carotenoids (Chl/Car) compared with those of the control (Fig. 2a, b). Both ratios became completely recovered within 5 days of recovery after the aLTS treatment. Both ratios significantly decreased to levels lower than those of the control plants under tLTS treatment (Fig. 2a, b), and both ratios slightly increased after 5 days of recovery. However, significant differences in each of the two ratios were observed between tLTS treatment and the control.

\section{RuBPCase activity}

Both aLTS and tLTS treatments significantly decreased RuBPCase activity compared with the control, particularly under tLTS treatment (Fig. 3). RuBPCase activity recovered within only 5 days of recovery after aLTS treatment.

\section{Hydrogen peroxide and malondialdehyde contents, $\mathrm{O}_{2}^{-}$ release rate, and anti-oxidative enzyme activities in chloroplasts}

Contents of MDA and $\mathrm{H}_{2} \mathrm{O}_{2}$ and release of $\mathrm{O}_{2}^{-}$in chloroplasts of the $K$. obovata leaves were significantly increased under aLTS and tLTS treatments (Fig. 4a, b and f). Only the contents of MDA and $\mathrm{H}_{2} \mathrm{O}_{2}$ and the release rate of $\mathrm{O}_{2}^{-}$in the chloroplasts recovered within 5 days of recovery after aLTS treatment. Significant differences in the contents of MDA and $\mathrm{H}_{2} \mathrm{O}_{2}$ and release rate of $\mathrm{O}_{2}^{-}$ were still observed in the chloroplasts between tLTS treatment and the control within 5 days of recovery after tLTS treatment.

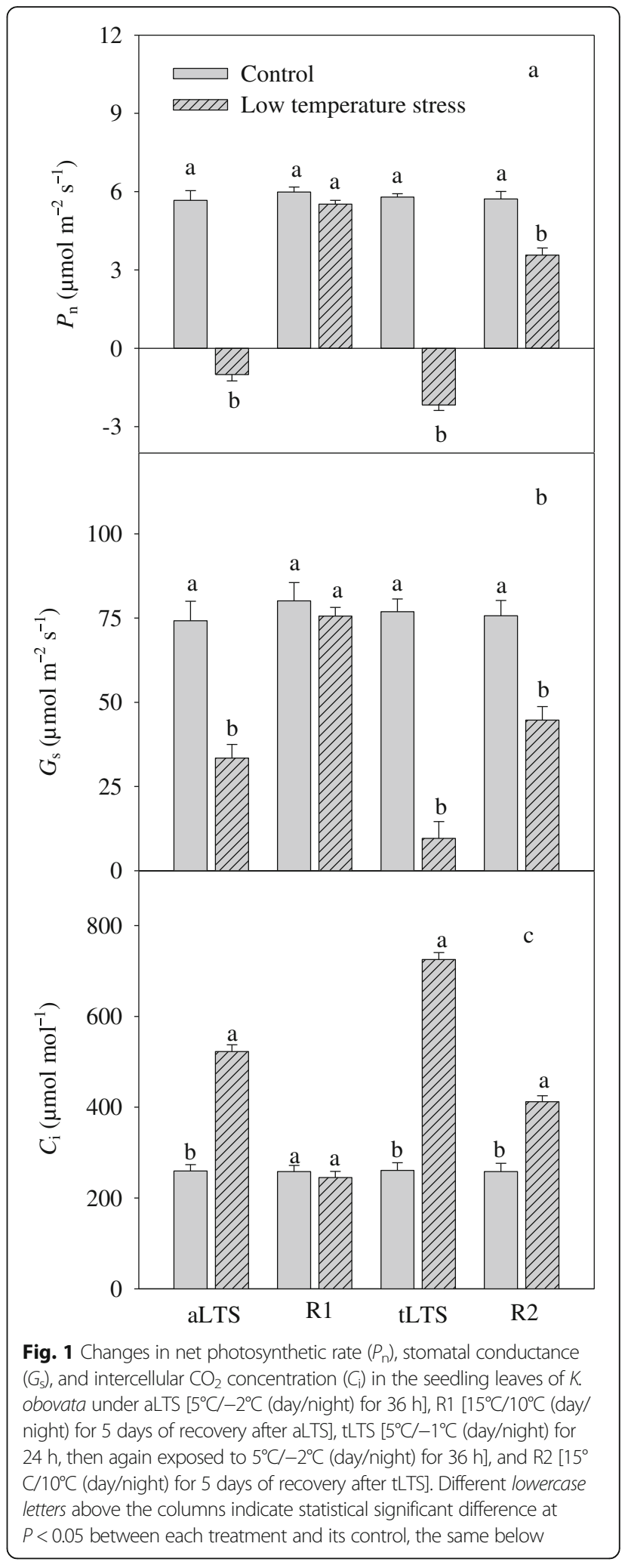

Compared with the control, treatment aLTS significantly increased the activities of SOD and POD in the chloroplasts (Fig. 4c, d). Both activities recovered within 


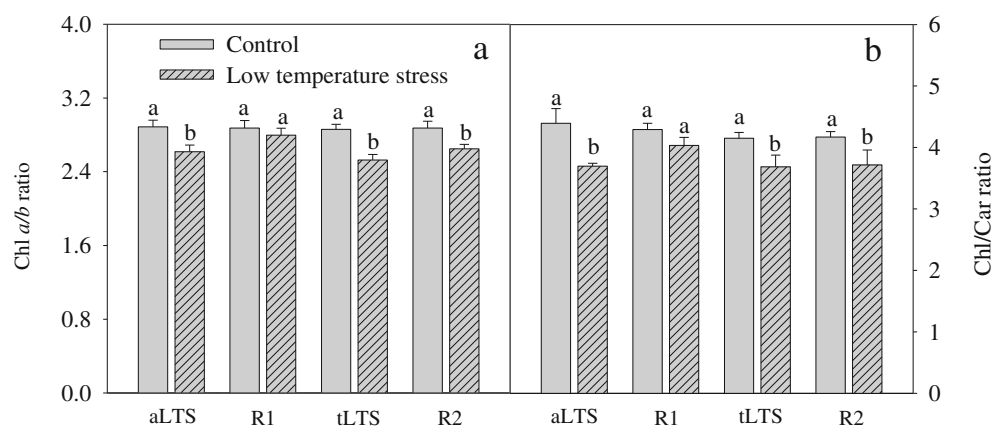

Fig. 2 Changes in ratios of chlorophyll a/b $(\mathrm{Chl} \mathrm{a} / \mathrm{b})$ and chlorophyll/carotenoid (Chl/Car) in the seedling leaves of K. obovata under aLTS $\left[5^{\circ} \mathrm{C} /-2^{\circ} \mathrm{C}\right.$ (day/night) for $\left.36 \mathrm{~h}\right], \mathrm{R} 1\left[15^{\circ} \mathrm{C} / 10^{\circ} \mathrm{C}\right.$ (day/night) for 5 days of recovery after aLTS $]$, tLTS $\left[5^{\circ} \mathrm{C} /-1{ }^{\circ} \mathrm{C}\right.$ (day/night) for $24 \mathrm{~h}$, then again exposed to $5^{\circ} \mathrm{C} /-2^{\circ} \mathrm{C}$ (day/night) for $\left.36 \mathrm{~h}\right]$, and $\mathrm{R} 2\left[15^{\circ} \mathrm{C} / 10^{\circ} \mathrm{C}\right.$ (day/night) for 5 days of recovery after tLTS]

5 days recovery treatment. However, treatment tLTS significantly decreased these activities, compared with the control plants. Subsequent recovery only slightly improved the activities of SOD and POD in chloroplasts; thus, significant differences were still observed between the treatments. Compared with the control, aLTS and tLTS treatments significantly decreased activity of APX (Fig. 4e). Activity of APX was recovered within only 5 days of recovery after aLTS treatment.

\section{TSS and sucrose contents and sucrose synthase and}

\section{sucrose phosphate synthase activities in leaves}

Compared with the control, treatment aLTS significantly increased contents of TSS and sucrose and activity of SS in leaves, while significantly decreased activity of SPS in leaves (Fig. 5a, d). However, contents of TSS and sucrose

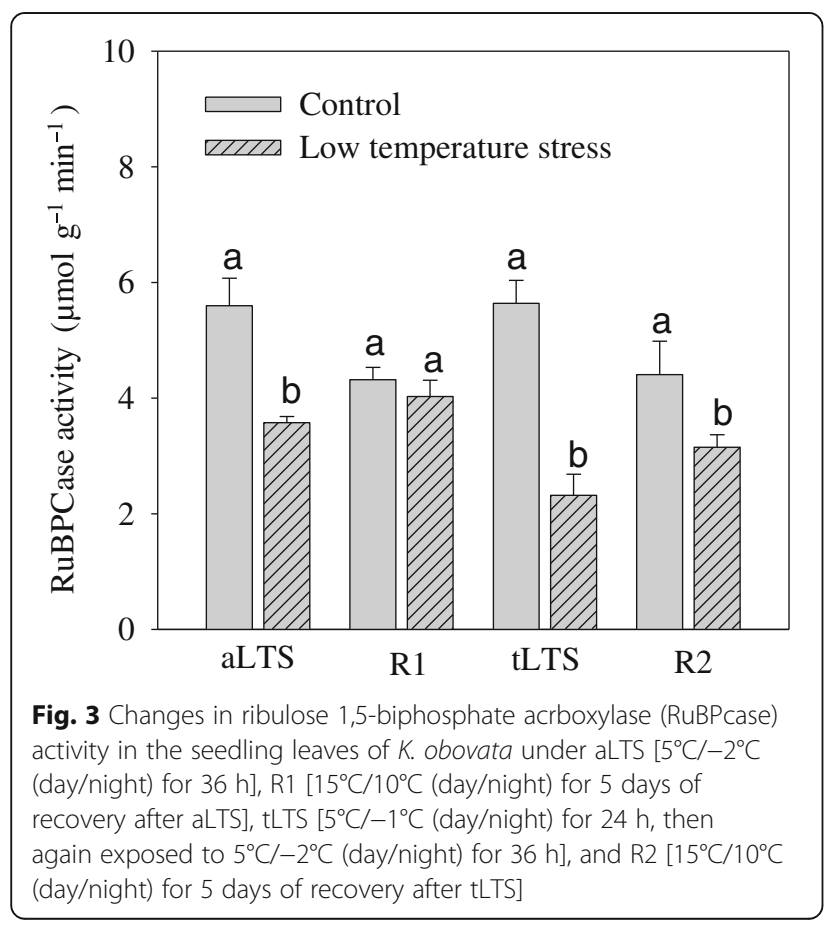

and activities of SS and SPS in leaves recovered after 5 days recovery treatment. Compared with the control, treatment tLTS significantly increased TSS content but reduced sucrose content and activities of SS and SPS (Fig. 5b, c). Significant differences in contents of TSS and sucrose and activities of SS and SPS were still observed between the stressed and control plants even after 5 days recovery treatment (Fig. 5a, b).

\section{Soluble protein and free amino acid contents and endopeptidase and carboxypeptidase activities} Compared with the control, aLTS and R1 increased contents of SP and free amino acid (FAA) and activity of carboxypeptidase in leaves but decreased activity of endopeptidase (Fig. 6a-d). Significant differences in the contents of SP and FAA and activities of endopeptidase and carboxypeptidase were only observed between aLTS treatment and the control (Fig. 6a-d). These differences were more significant than those between tLTS treatment and the control. Additionally, there were still significant differences in the contents of SP and FAA and activities of endopeptidase and carboxypeptidase between low temperature stress and control plants after 5 days recovery treatment (Fig. 6a-d).

\section{Correlation coefficient among physiological indices}

$P_{\mathrm{n}}$ was significantly positively correlated with $G_{\mathrm{s}}$, ratios of $\mathrm{Chl} \mathrm{a/b}$ and Chl/Car, activities of APX and SOD in chloroplasts, and activities of RuBPCase, SS, SPS, and endopeptidase in leaves $(p<0.01$, Table 1$)$. By contrast, $P_{\mathrm{n}}$ was significantly negatively correlated $(p<0.01)$ with $C_{\mathrm{i}}$, contents of MDA and $\mathrm{H}_{2} \mathrm{O}_{2}$ and release rate of $\mathrm{O}_{2}^{-}$in the chloroplasts, contents of TSS, SP, and FAA, and activity of carboxypeptidase in the leaves.

\section{Discussion}

Exposure of $K$. obovata seedlings to low temperature reduces $P_{\mathrm{n}}$ and $G_{\mathrm{s}}$ (Kao et al. 2004). After a rare cold event 


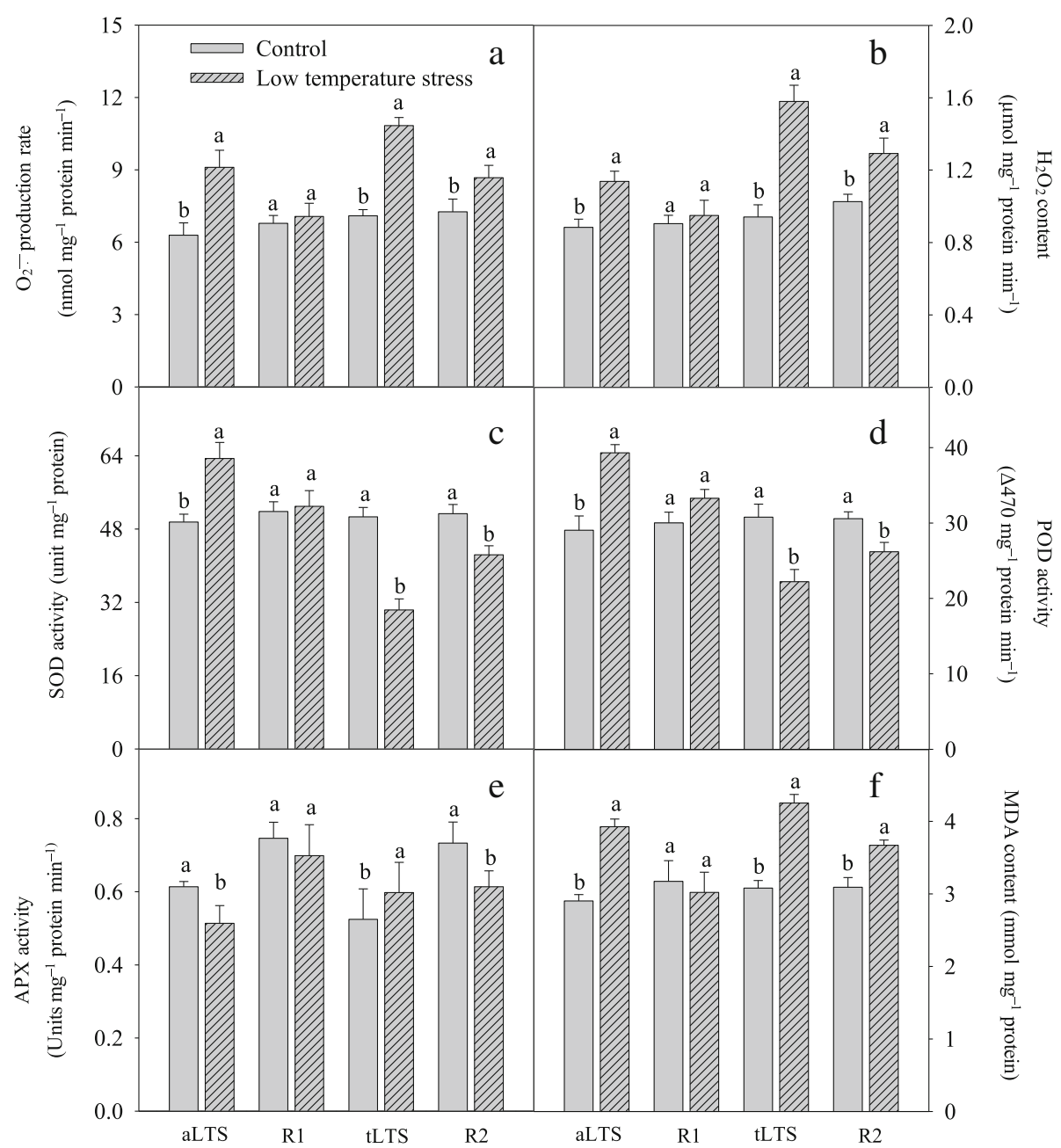

Fig. 4 Changes in $\mathrm{O}_{2}^{-}$production rate, hydrogen peroxide $\left(\mathrm{H}_{2} \mathrm{O}_{2}\right)$ release, activities of superoxide dismutase (SOD), peroxidase (POD) and ascorbate peroxidase (APX), and malondialdehyde (MDA) content in chloroplasts in seedling leaves of $\mathrm{K}$. obovata under aLTS $\left[5^{\circ} \mathrm{C} /-2^{\circ} \mathrm{C}(\right.$ day/ night) for $36 \mathrm{~h}]$, R1 $\left[15^{\circ} \mathrm{C} / 10^{\circ} \mathrm{C}\right.$ (day/night) for 5 days recovery after aLTS], tLTS $\left[5^{\circ} \mathrm{C} /-1^{\circ} \mathrm{C}\right.$ (day/night) for $24 \mathrm{~h}$, then again exposed to $5^{\circ} \mathrm{C} /-2^{\circ} \mathrm{C}$ (day/night) for $36 \mathrm{~h}]$, and $\mathrm{R} 2\left[15^{\circ} \mathrm{C} / 10^{\circ} \mathrm{C}\right.$ (day/night) for 5 days recovery after tLTS]

in winter of 2010, the recovery of photosynthetic capacity in $K$. obovata seedlings in the northern limit of introduced mangroves in China is difficult during a short period (Zheng et al. 2016). In the present study, $P_{\mathrm{n}}$ rapidly decreased after low temperature stress treatments, particularly tLTS treatment. The seedlings could not recover photosynthesis efficiency even for 5 days recovery treatment under optimum conditions after tLTS treatment (Fig. 6). This indicated that seLTS inhibited recovery of $P_{\mathrm{n}}$ in $K$. obovata seedlings. In general, $P_{\mathrm{n}}$ is affected by stomatal and non-stomatal factors. Stomatal or non-stomatal limitation on $P_{\mathrm{n}}$ depends on changes in $C_{\mathrm{i}}$ (Farquhar and Sharkey 1982). In addition, it is reported that non-stomatal limitations of $P_{\mathrm{n}}$ to $C_{\mathrm{i}}$ and biochemical assay were related to the decline in the activity of RuBPCase (Ziska et al. 1990). The seedlings of K. obovata were subjected to aLTS and tLTS treatments and were returned to the initial growth conditions to assess their response during recovery. Treatment aLTS significantly decreased $P_{\mathrm{n}}$ and $G_{\mathrm{s}}$ in leaves with increasing $C_{\mathrm{i}}$. And RuBPCase activity was significantly decreased under aLTS treatment. This suggested that reduction in $P_{\mathrm{n}}$ under aLTS treatment could be principally ascribed to non-stomatal limitation. Recovery for 5 days at $10 / 15^{\circ} \mathrm{C}$ (day/night) was sufficient for complete recovery of photosynthesis from aLTS treatment, while the photosynthetic capacity was not recovered under tLTS treatment.

$P_{\mathrm{n}}$ positively correlated with ratios of $\mathrm{Chl} \mathrm{a} / \mathrm{b}$ and $\mathrm{Chl} /$ Car in leaves (Table 1). This suggested that decreases in ratios of $\mathrm{Chl} \mathrm{a} / \mathrm{b}$ and $\mathrm{Chl} / \mathrm{Car}$ in leaves limit photosynthesis under low temperature stress. In the present study, decreases in ratio of $\mathrm{Chl} \mathrm{a} / \mathrm{b}$ in leaves under low temperature stress and subsequent recovery resulted 


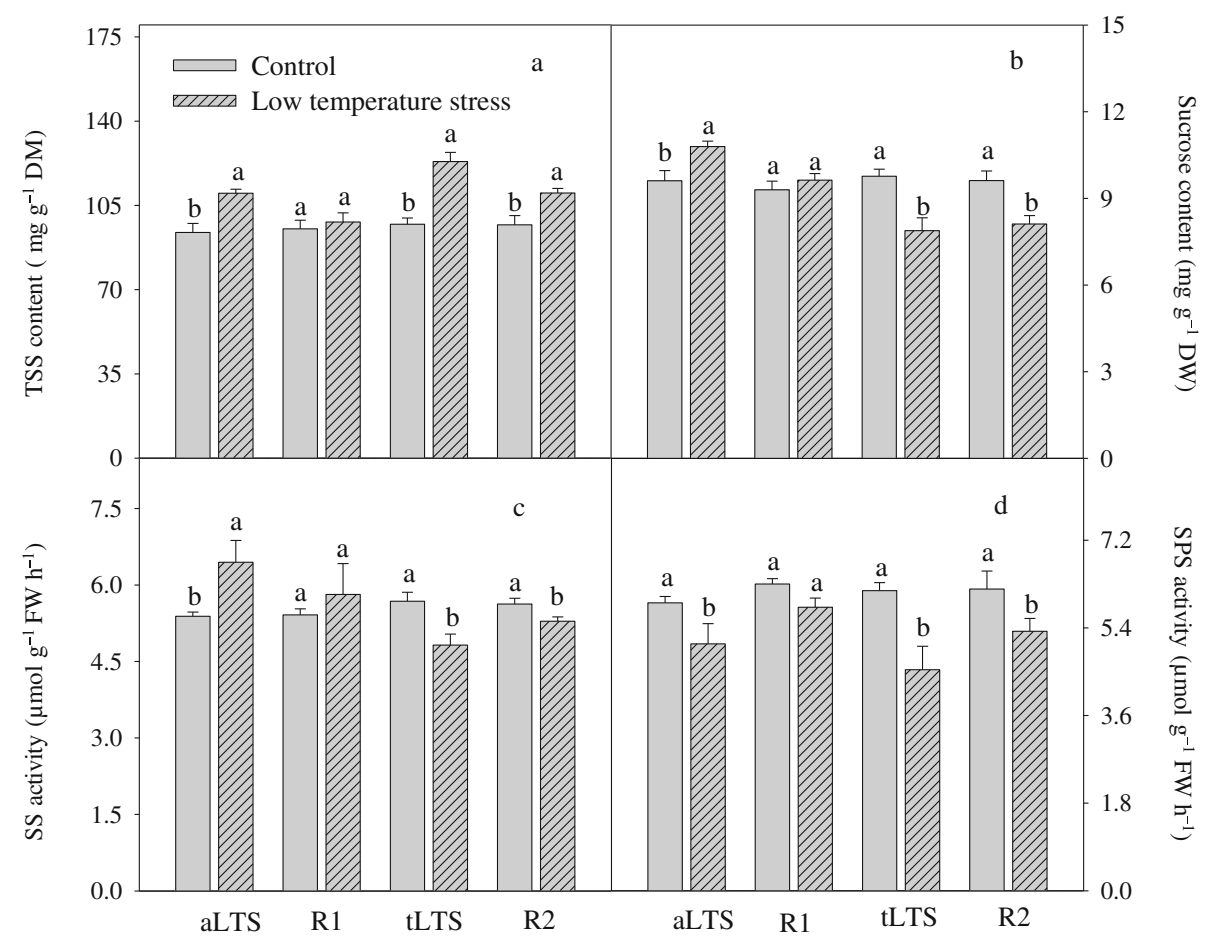

Fig. 5 Changes in contents of total soluble sugar (TSS) and sucrose and activities of sucrose synthase (SS) and sucrose phosphate synthase (SPS) in the seedling leaves of $\mathrm{K}$. obovata under aLTS $\left[5^{\circ} \mathrm{C} /-2^{\circ} \mathrm{C}\right.$ (day/night) for $\left.36 \mathrm{~h}\right]$, R1 $\left[15^{\circ} \mathrm{C} / 10^{\circ} \mathrm{C}\right.$ (day/night) for 5 days of recovery after aLTS], tLTS $\left[5^{\circ} \mathrm{C} /-1^{\circ} \mathrm{C}\right.$ (day/night) for $24 \mathrm{~h}$, then again exposed to $5^{\circ} \mathrm{C} /-2^{\circ} \mathrm{C}$ (day/night) for $\left.36 \mathrm{~h}\right]$, and $\mathrm{R} 2\left[15^{\circ} \mathrm{C} / 10^{\circ} \mathrm{C}\right.$ (day/night) for 5 days of recovery after tLTS]

Table 1 Correlation coefficients between net photosynthetic rate $(\mathrm{Pn})$ and physiological indices in K. obovata

\begin{tabular}{lr}
\hline Parameters & \\
\hline Stomatal conductance $\left(G_{5}\right)$ & $0.963^{* *}$ \\
Intercellular $\mathrm{CO}_{2}$ concentration $\left(\mathrm{C}_{\mathrm{i}}\right)$ & $-0.962^{* *}$ \\
Chlorophyll a/chlorophyll b $(\mathrm{Chl}$ a/b) ratio & $0.677^{* *}$ \\
Chlorophyll/carotenoid (Chl/Car) ratio & $0.779^{* *}$ \\
Ribulose 1,5-biphosphate acrboxylase (RuBPcase) & $0.564^{* *}$ \\
Ascorbate peroxidase (APX) & $0.575^{* *}$ \\
Superoxide dismutase (SOD) & $0.544^{* *}$ \\
Peroxidase (POD) & 0.327 \\
Malondialdehyde (MDA) & $-0.918^{* *}$ \\
Superoxide anion ( $\left.\mathrm{O}_{2}^{-}\right)$ & $-0.935^{* *}$ \\
Hydrogen peroxide $\left(\mathrm{H}_{2} \mathrm{O}_{2}\right)$ & $-0.913^{* *}$ \\
Total soluble sugar $(\mathrm{TSS})$ & $-0.931^{* *}$ \\
Sucrose & 0.398 \\
Sucrose synthase (SS) & 0.265 \\
Sucrose phosphate synthase (SPS) & $0.914^{* *}$ \\
Soluble protein (SP) & $-0.947^{* *}$ \\
Free amino acid (FAA) & $-0.926^{* *}$ \\
Endopeptidase & $0.921^{* *}$ \\
Carboxypeptidase & $-0.940^{* *}$ \\
\hline
\end{tabular}

**Significant correlation at $P<0.01$ from more increases in Chl b than in Chl a. One explanation is that, when $\mathrm{Chl}$ a preferential assembling reaction centers are limited, the reaction centers no longer incorporate the majority of $\mathrm{Chl}$ a. Thus chlorophyllide a oxygenase synthesizes $\mathrm{Chl} b$ in significant amounts (Wu et al. 2007). In addition, low ratios of $\mathrm{Chl} / \mathrm{Car}$ in leaves under low temperature stress and subsequent recovery could be attributed to the faster decreases in Chl than in Car. These indicated that aberration of Chl synthase function decreases $\mathrm{Chl}$ a synthesis. Moreover, ratios of $\mathrm{Chl} \mathrm{a} / \mathrm{b}$ and $\mathrm{Chl} / \mathrm{Car}$ in leaves under tLTS treatment were lower than those of aLTS treatment, indicating that seLTS more severely affected pigment components, in accordance with the findings from Zheng et al. (2013).

Reduction in $P_{\mathrm{n}}$ under low temperature stress is associated with increase in ROS in the chloroplasts of cucumber, and low temperature increases activities of SOD and APX in chloroplasts (Hu et al. 2008). In the present study, although activities of APX and POD increased, decreases in SOD activity would still probably lead to the accumulation of $\mathrm{H}_{2} \mathrm{O}_{2}$ and $\mathrm{O}_{2}^{-}$in chloroplasts for the first low temperature injury. This is in accordance with the findings of Peng et al. (2015). And levels of $\mathrm{H}_{2} \mathrm{O}_{2}, \mathrm{O}_{2}^{-}$, and MDA in chloroplasts recovered after the first recovery period of $48 \mathrm{~h}$ under control conditions (Fig. 3a, b, and d). However, treatment tLTS aggravated 


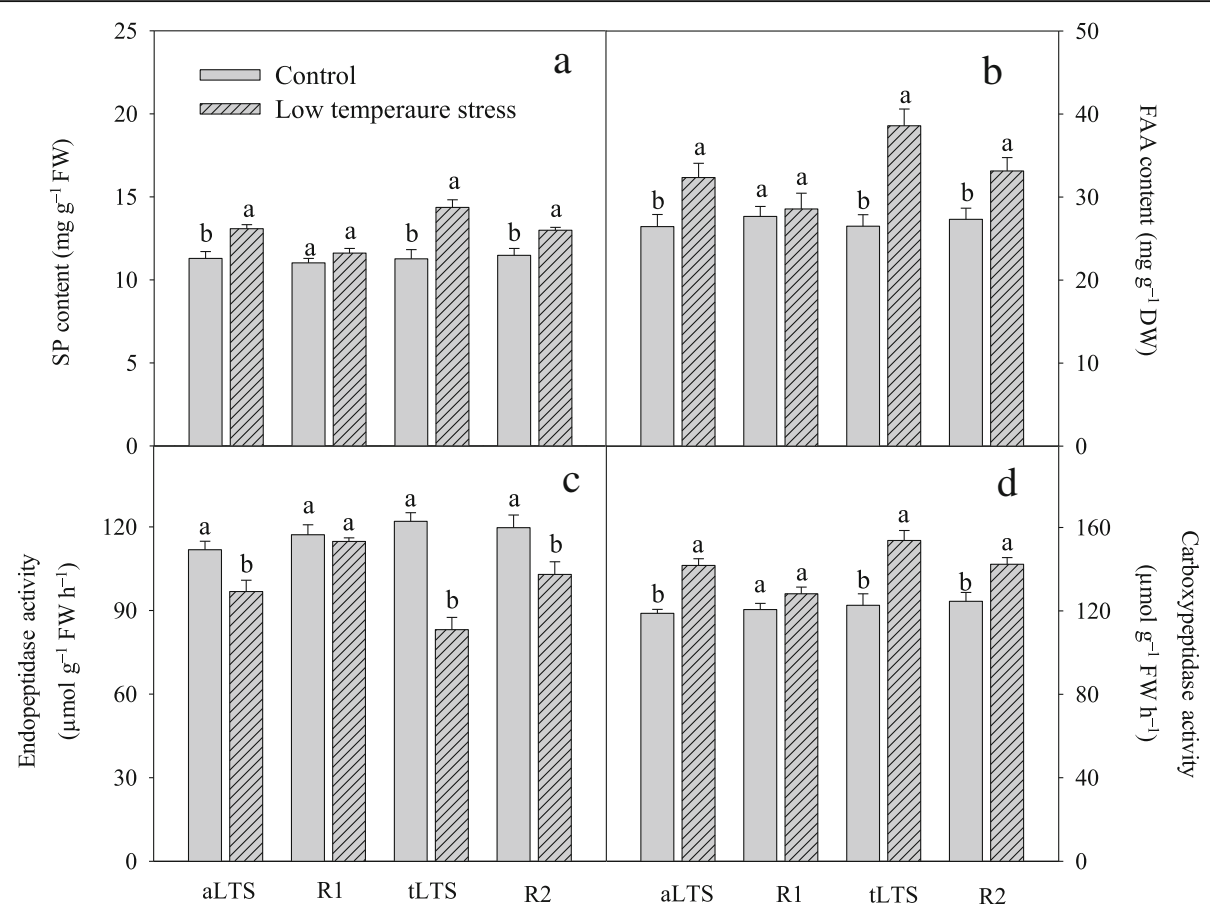

Fig. 6 Changes in contents of soluble protein (SP) and free amino acid (FAA) and activities of endopeptidase and carboxypeptidase in the seedling leaves of $K$. obovata under aLTS $\left[5^{\circ} \mathrm{C} /-2^{\circ} \mathrm{C}\right.$ (day/night) for $\left.36 \mathrm{~h}\right], \mathrm{R} 1\left[15^{\circ} \mathrm{C} / 10^{\circ} \mathrm{C}\right.$ (day/night) for 5 days of recovery after aLTS], tLTS $\left[5^{\circ} \mathrm{C} /-1^{\circ} \mathrm{C}\right.$ (day/night) for $24 \mathrm{~h}$, then again exposed to $5^{\circ} \mathrm{C} /-2^{\circ} \mathrm{C}$ (day/night) for $\left.36 \mathrm{~h}\right]$, and $\mathrm{R} 2\left[15^{\circ} \mathrm{C} / 10^{\circ} \mathrm{C}\right.$ (day/night) for 5 days of recovery after $\mathrm{LLTS}]$

damage extent and then depressed activities of SOD, POD, and APX and caused massive accumulation of $\mathrm{H}_{2} \mathrm{O}_{2}, \mathrm{O}_{2}^{-}$, and MDA in chloroplasts. This indicated that seLTS induced oxidative bursts because of ROS overproduction in chloroplasts, thereby reduced utilization of the absorbed light energy for $\mathrm{CO}_{2}$ assimilation. Correlation coefficients between $P_{\mathrm{n}}$ and activities of APX, SOD, and POD, and levels of $\mathrm{H}_{2} \mathrm{O}_{2}, \mathrm{O}_{2}^{-}$, and MDA in chloroplasts agreed with this proposition. After the plants were subjected to two freezing injuries, levels of $\mathrm{H}_{2} \mathrm{O}_{2}, \mathrm{O}_{2}^{-}$, and MDA and activities of SOD, POD, and APX did not recover even when they were transferred to control conditions for 5 days.

Sucrose metabolism is crucial to carbohydrate translocation and accumulation, and low temperature stress might impair sucrose translocation (Artuso et al. 2000). Photosynthesis rate also determines sucrose content in sugarcane leaves exposed to low temperature stress ( $\mathrm{Du}$ and Nose 2002). Therefore, positive relationship between $P_{\mathrm{n}}$ and sucrose content indicated that decreases in $P_{\mathrm{n}}$ restrained sucrose synthesis under low temperature. Sucrose synthesis and/or degradation referred to SPS and SS. Genetically, SPS catalyzes a step in sucrose synthesis. In addition, protein SS is preferentially expressed during cold stress, suggesting that the enzyme might be involved in plant responses to low temperature stress (Crespi et al. 1991). SS participates in sucrose cleavage or sucrose synthesis. In the present study, SS activity in leaves increased after aLTS treatment, but recovered after treatment R1. Meanwhile, treatment aLTS significantly increased contents of TSS and sucrose but decreased activity of SPS. These suggested that SS activity in leaves during aLTS treatment participated in sucrose synthesis and that sucrose accumulation induced by low temperature injury principally depended on increases in SS activity. Treatment tLTS significantly reduced content of sucrose and activities of SS and SPS but significantly increased content of TSS. These parameters did not recover even after 5 days recovery treatment, suggesting that sucrose metabolism in K. obovata leaves was deteriorated after seLTS treatment. It was also found that sucrose acted as a direct ROS scavenger (Van den Ende and Valluru 2009). Therefore, decreases in sucrose content in leaves might also account for increases in ROS in chloroplasts.

Decreases in SP and increases in free amino acids might be related with activities of endopeptidase and carboxpeptidase (Cohen and Demaggio 1986). Endopeptidase is a protease that catalyzes the cleavage of peptide bonds within a polypeptide or protein, and carboxypeptidase is another protease enzyme that hydrolyzes (cleaves) a peptide bond at the C-terminal end of a protein or peptide, which has a stronger preference for free amino acids. In the present study, aLTS and tLTS 
treatments improved the accumulation of SP and FAA and activity of carboxypeptidase but decreased activity of endopeptidase, indicating that carboxypeptidase was critical to cleave peptide bonds for FAA. In addition, the principal reason for protein degradation under low temperature stress is the accumulation of ROS that promotes oxidation of proteins and lipids and inhibits activity of endopeptidase (Prasad 1996). Protein degradation in $K$. obovata was completely recovered after $\mathrm{R} 1$, but proteolysis was insufficiently recovered after R2. Furthermore, FAA content positively correlated with carboxypeptidase activity but negatively correlated with endopeptidase activity, indicating that low temperature stress induced senescence of endopeptidase but improved efficiency of carboxypeptidase to synthesize FAA.

\section{Conclusions}

In conclusion, tLTS treatment decreased $P_{\mathrm{n}}$ in the leaves of $K$. obovata seedlings because of stomatal closure and non-stomatal factors. Increase in $C_{\mathrm{i}}$ might be partly explained by declined ratios of $\mathrm{Chl} \mathrm{a} / \mathrm{b}$ and $\mathrm{Chl} / \mathrm{Car}$, enhanced peroxidation in chloroplasts, weakened activities of sucrose-metabolizing enzymes, and accelerated senescence of endopeptidase. Therefore, photosynthetic capacity could not completely recover after tLTS treatment.

\section{Acknowledgments}

This study was funded by the projects of Special Funding for Research of National Oceanic Public Service Industry (201505028), Zhejiang Provincial Natural Science Foundation (LQ13C030002), Science and Technology Plan of Zhejiang Province (2012C12017-3, 2013C25096, and 2014F50003), China and Israel Cooperation Project (2015), and Wenzhou Municipal Science and Technology Plan Project (\$20110007).

\section{Authors' contributions}

WL, YY, CZ, and JT designed the study and collected and analyzed the data. $C Z, J C, J Q$, and XP performed the experiment work and analyzed the data. $\mathrm{CZ}$ and JT drafted the manuscript. All authors read and approved the final manuscript.

\section{Competing interests}

The authors declare that they have no competing interests.

\section{Author details}

'Zhejiang Mariculture Research Institute, Zhejiang Key Laboratory of Exploitation and Preservation of Coastal Bio-resource, Wenzhou 325005, Zhejiang, People's Republic of China. ${ }^{2}$ Nanji Islands National Marine Nature Reserve Administration, Pingyang 325401, People's Republic of China. ${ }^{3}$ Key Laboratory of the Ministry of Eduction for Coastal and Wetland Ecosystem, College of the Environment and Ecology, Xiamen University, Xiamen 361005, People's Republic of China.

Received: 24 August 2016 Accepted: 7 November 2016 Published online: 25 November 2016

\section{References}

Analuddin KS, Sharma S, Suwa R, Hagihara A (2009) Crown foliage dynamics of mangrove Kandelia obovata in Manko wetland, Okinawa Island, Japan. J Oceanogr 65:121-127

Arnon D (1949) Copper enzymes in isolated chloroplasts. Polyphenoloxidase in Beta vulgaris. Plant Physiol 24:1-5
Artuso A, Guidi L, Soldatini GF, Pardossi A, Tognoni F (2000) The influence of chilling on photosynthesis and activities of some enzymes of sucrose metabolism in Lycopersicon esculentum Mill. Acta Physiol Plant 22:95-101

Bradford M (1976) A rapid and sensitive method for the quantitation of microgram quantities of protein utilizing the principle of protein-dye binding. Anal Biochem 72:248-254

Cohen H, Demaggio AE (1986) Biochemistry of fern spore germination: protease activity in ostrich fern spores. Plant Physiol 80:992-996

Crespi M, Zabaleta E, Pontis H, Salerno G (1991) Sucrose synthase expression during cold acclimation in wheat. Plant Physiol 96:887-891

Du Y, Nose A (2002) Effects of chilling temperature on the activity of enzymes of sucrose synthesis and the accumulation of saccharides in leaves of three sugarcane cultivars differing in cold sensitivity. Photosynthetica 40:389-395

Ellis WL, Bowles JW, Erickson AA, Stafford N, Bell SS, Thomas M (2006) Alteration of the chemical composition of mangrove (Laguncularia racemosa) leaf litter fall by freeze damage. Estuar Coast Shelf Sci 68:363-371

Farquhar GD, Sharkey TD (1982) Stomatal conductance and photosynthesis. Annu Rev Plant Physiol 33:317-345

Fahnenstich H, Scarpeci TE, Valle EM, Flügge UI, Maurino VG (2008) Generation of hydrogen peroxide in chloroplasts of Arabidopsis overexpressing glycolate oxidase as an inducible system to study oxidative stress. Plant Physiol 148: $719-729$

Giannopolitis C, Ries S (1977) Superoxide dismutases: I. Occurrence in higher plants. Plant Physiol 59:309-314

Gilman EL, Ellison J, Duke NC, Field C (2008) Threats to mangroves from climate change and adaptation options: a review. Aquat Bot 89:237-250

Haines BL, Dunn EL (1976) Growth and resource allocation responses of Spartina alterniflora Loisel. to three levels of $\mathrm{NH}_{4}^{+}-\mathrm{N}$, $\mathrm{Fe}$ and $\mathrm{NaCl}$ in solution culture. Bot Gaz 137:224-230

Hendrix DL (1993) Rapid extraction and analysis of nonstructural carbohydrates in plant tissues. Crop Sci 33:1306-1311

Hodges D, Delong J, Forney C, Prange R (1999) Improving the thiobarbituric acidreactive-substances assay for estimating lipid peroxidation in plant tissues containing anthocyanin and other interfering compounds. Planta 207:604-611

Hu W, Song X, Shi K, Xia X, Zhou Y, Yu J (2008) Changes in electron transport, superoxide dismutase and ascorbate peroxidase isoenzymes in chloroplasts and mitochndria of cucumber leaves as infulenced by chilling. Photosynthetica 46:581-588

Hubbard NL, Huber SC, Pharr DM (1989) Sucrose phosphate synthase and acid invertase as determinants of sucrose concentration in developing Muskmelon (Cucumis melo L.) fruits. Plant Physiol 91: 1527-1534

Kao WY, Shih CN, Tsai TT (2004) Sensitivity to chilling temperatures and distribution differ in the mangrove species Kandelia candel and Avicennia marina. Tree Physiol 24:859-864

Lee MA, Chun HS, Kim JW, Lee H, Lee DL, Lee CB (2004) Changes in antioxidant enzyme activities in detached leaves of cucumber exposed to chilling. J Plant Biol 47:117-123

Lee T, Lin Y (1995) Change in soluble and cell wall-bound peroxidase activities with growth in anoxia-treated rice (Oryza sativa L.) coleoptiles and roots. Plant Sci 106:1-7

Li X, Gong B, XU K (2014) Interaction of nitric oxide and polyamines involves antioxidants and physiological strategies against chilling-induced oxidative damage in Zingiber officinale Roscoe. Sci Hortic 170:237-248

Liu K, Liu L, Liu H, Li X, Wang S (2014) Exploring the effects of biophysical parameters on the spatial pattern of rare cold damage to mangrove forests. Remote Sens Environ 150:20-33

Mehta R, Mattoo A (1996) Isolation and identification of ripening-related tomato fruit carboxypeptidase. Plant Physiol 110:875-882

Moore S, Stein WH (1954) A modified ninhydrin reagent for the photometric determination of amino acids and related compounds. J Biol Chem 211:907-913

Moloi MJ, van der Westhuizen AJ (2006) The reactive oxygen species are involved in resistance responses of wheat to the Russian wheat aphid. J Plant Physiol 163:1118-1125

Naidoo G (2016) The mangrove of South Africa: An ecophysiological review. S Afr J Bot http://dx.doi.org/10.1016/j.sajb.2016.04.014

Nakano Y, Asada K (1981) Hydrogen peroxide is scavenged by ascorbate-specific peroxidase in spinach chloroplasts. Plant Cell Physiol 22:867-880

Peng Y, Wang Y, Chen H, Sun C, Wu P, Wang L (2013) Characterization and expression analysis of three CBF/DREB1 transcriptional factor genes from mangrove Avicennia marina. Aquat Toxicol 140-141:68-76 
Peng Y, Wang Y, Fei J, Sun C, Cheng H (2015) Ecophysiological differences between three mangrove seedlings (Kandelia obovata, Aegiceras corniculatum, and Avicennia marina) exposed to chilling stress. Ecotoxicology 24:1722-1732

Prasad TK (1996) Mechanisms of chilling-induced oxidative stress injury and tolerance in developing maize seedlings: changes in antioxidant system, oxidation of proteins and lipids, and protease activities. Plant J 10:1017-1026

Quisthoudt K, Schmitz N, Randin C, Dahdouh-Guebas F, Robert E, Koedam N (2012) Temperature variation among mangrove latitudinal range limits worldwide. Trees 26:1919-1931

Ross M, Ruiz P, Sah J, Hanan E (2009) Chilling damage in a changing climate in coastal landscapes of the subtropical zone: a case study from south Florida. Global Chang Biol 20:147-157

Saintilan N, Wilson NC, Rogers K, Rajkaran A, Krauss KW (2014) Mangrove expansion and salt marsh decline at mangrove poleward limits. Global Chang Biol 20:147-157

Seigneurin-Berny D, Salvi D, Dorne A, Joyard J, Rolland NH (2008) Percoll-purified and photosynthetically active chloroplast from Arabidopsis thaliana leaves. Plant Physiol Biochem 158:847-852

Sheue CR, Liu HY, Yong JWH (2003) Kandelia obovata (Rhizophoraceae), a new mangrove species from Eastern Asia. Taxon 52:287-294

Stevens P, Fox S, Montague C (2006) The interplay between mangroves and saltmarshes at the transition between temperature and subtropical climate in Florida. Wetl Ecol Manag 14:435-444

Stuart SA, Choat B, Martin KC, Holbrook NM, Ball MC (2006) The role of freezing in setting the latitudinal limits of mangrove forests. New Phytol 173:576-583

Sui N, Li M, Liu XY, Wang N, Fang W, Meng QW (2007) Response of xanthophyll cycle and chloroplastic antioxidant enzymes to chilling stress in tomato over-expressing glycerol-3-phosphate acyltransferase gene. Photosynthetica 45:447-454

Sui X, Zhang B, Zhang Z, Mao SL, Wang L (2005) Differences of photosynthetic characteristics and low light-tolerance in seedlings of four pepper cultivars. Acta Hortic Sin 32: 222-227

Van den Ende W, Valluru R (2009) Sucrose, sucrosyl oligosaccharides, and oxidative stress: scavenging and salvaging? J Exp Bot 60:9-18

Wang W, You S, Wang Y, Huang L, Wang M (2011) Influence of frost on nutrient resorption during leaf senescence in a mangrove at its latitudinal limit of distribution. Plant Soil 342:105-115

Wang XD, Yu ZW, Wang D (2003) Effect of potassium on flag leaf proteinases activity and kernel quality in wheat. Acta Agron Sin 29:285-289

Wu Z, Zhang X, He B, Diao L, Sheng S, Wang J, Guo X, Su N, Wang L, Jiang L, Wang C, Zhai H, Wan J (2007) A chlorophyll-deficient rice mutant with impaired chlorophyllide esterification in chlorophyll biosynthesis. Plant Physiol 145:29-40

Zhang X, Jiang D, Zheng C, Dai T, Cao W (2011) Post-anthesis salt and combination of salt and waterlogging affect distributions of sugars, amino acids, $\mathrm{Na}^{+}$and $\mathrm{K}^{+}$in wheat. J Agron Crop Sci 197:31-39

Zheng C, Liu W, Qiu J, Huang L, Huang X, Chen S (2013) Comparison of physiological characteristics of Kandelia obovata at different ages in winter in the northernmost mangrove transplanted area of China. Acta Ecol Sin 33:132-138

Ziska LH, Seemann JR, DeJong TM (1990) Salinity induced limitations on photosynthesis in Prunus salicina, a deciduous tree species. Plant Physiol 93:864-870

Zheng C, Ye Y, Liu W, Tang J, Zhang C, Qiu J, Chen J (2016) Recovery of photosynthesis, sucrose metabolism, and proteolytic enzymes in Kandelia obovata from rare cold events in the northernmost mangrove, China. Ecol Process 5:9

\section{Submit your manuscript to a SpringerOpen ${ }^{\mathcal{O}}$ journal and benefit from:}

- Convenient online submission

- Rigorous peer review

- Immediate publication on acceptance

- Open access: articles freely available online

- High visibility within the field

- Retaining the copyright to your article

Submit your next manuscript at $\gg$ springeropen.com 